TURIZAM

Volume 22, Issue 1

19-31 (2018)

ORIGINAL

SCIENTIFIC PAPER

\section{Touristic Events as Generators of Visitations Increase and Tourism Sustainability of Nature Parks in Continental Croatia?}

\author{
Božidar Jaković ${ }^{*}$, Dejan TubićA, Rikard Bakan ${ }^{A}$ \\ Received: March 2018 | Accepted: April 2018
}

DOI: $10.5937 / 22-17509$

\begin{abstract}
The protected areas of nature in the 21st century record continuous growth, since they can satisfy diverse desires, needs and expectations of contemporary and extremely fragmented tourist demand. However, level of visit greatly depend on the category, resource attractiveness, additional supply and other authentic features of the protected area. According to that, in some of the recently established nature parks, tourism still does not sufficiently contribute to the economic sustainability of their own park agencies, and even less to the local community. Although long-term financial independence of park agencies and the survival of nature parks is questionable, currently there is no clear interest in Croatia in exploring this field. The main purpose of this paper is to determine to what extent tourist events can contribute to increasing recognisability, level of visit and the economic sustainability of nature parks. For this purpose, the research was carried out on all five Public institutions of nature parks (PINPs) in continental Croatia. Primary data was conducted by a semi-structured interview. An essential feature of these five nature parks is that they are far from the major receptive mass tourism destinations, which differentiates them from those who are significantly more receptive due to these circumstances. Research findings suggest that touristic events, which are a significant factor in seasonality reduction, bring a multiple benefit for nature parks such as increasing level of visit, recognisability, image creation etc. However, they do not contribute to the economic sustainability of nature parks due to their unprofitability. In addition to events, the results indicate that nature parks should develop other, accompanying tourist attractions and facilities considering their lower rank of protection.
\end{abstract}

Keywords: protected areas, nature parks, touristic events, increasing level of visit, tourism sustainability of nature parks

A College of Tourism and IT Management in Virovitica, Department of Tourism, Matije Gupca 78, 3300o Virovitica, Croatia

* Corresponding author: bozidar.jakovic@vsmti.hr 


\section{Introduction}

The establishment of protected areas represents one of the most effective ways of protecting and preserving natural and cultural-historical resources. However, it is necessary to demonstrate that the benefits are higher than the cost of establishing (Dharmarante et al., 200o). This is why the relationship between tourism and protected areas lasts from the very beginnings of the establishment, where tourism is a key component in the establishment and management of protected area (Eagles et al., 2002). As some authors stated (Bushell, Eagles, 2006; Scheppard, 2006), tourism can provide a key means for protected area agencies to realize their objectives, but in addition to benefits, it can brings damages from the ecological, economic and sociocultural aspect. Tourism in protected areas largely depends on the level of attractiveness of resources, but also on the ability to preserve the quality of resources that tourism is based on. Protected areas have the considerable power of attracting a greater number of visitors, especially protected areas of high nature attractiveness, such as national parks. However, the level of visit among national parks is not the same.

At the very end of the twentieth century, new nature parks were proclaimed in Croatia. The establishment of these parks represents a great contribution to the preservation of natural and cultural heritage. However, due to the lower income from the founder and the level of visit that cannot generate enough revenues, most nature parks are looking for ways in order to be economically sustainable, especially those in continental Croatia. In addition, according to the Nature Protection Act (NN, 80/13), nature parks are a lower rank of protection and there are greater economic opportunities in using resources opposed to national parks.

An aggravating circumstance of the level of visit is the low interests of international tourism demand, due to the lack of recognition of nature parks. One of the consequences of that is incompatibility of such categories with the categories of International Union for Conservation of Nature (IUCN), so there is no recognisability, neither the value as globally known and uniquely categorized national parks. Insufficient number of visitors at nature parks and other areas of lower legal protection certainly have a positive and negative effect. The positive effect refers to the undisturbed sustainability of the ecosystem, while the negative impact reflects on the low revenue of the PINPs and the local community. Less strict legal regulations of nature parks open many possibilities, primarily through significant investments into accompanying products and services, creation of unique attractions and tourist facilities. This may primarily relate to the creation of e.g. cycling and other tourist paths, accommodation and other supporting facilities, organization of various events, from active, sports-competitive to various passive relaxing and others.

According to inability to attract more visitors, it is necessary to investigate and determine whether events could be generators of positive effects in nature parks. In order to improve the recent situation, an empirical research has been conducted, with the purpose of determining the possibilities and the limitations in developing and organising events, as the core of the increasing level of visit and the economic sustainability of nature parks. The theoretical level of the paper provides a better understanding of the importance of tourist events in increasing competitiveness of tourism destinations. In addition, through empirical research, it is determined whether tourism events that take place can be the generators of sustainable tourism development of nature parks. It is to expect that on the conducted level, paper will assure the increase of number of touristic events, which will lead to the better positioning on tourism market and would achieve sustainable and more competitive development of nature parks. 


\section{Literature Review}

Protected areas, especially national parks, all over the world represent a unique, highly ranked tourist attraction (Mayer, 2014), which will continue to grow on tourism market. According to the great interest of visitors and more intensive tourism development in national parks, the interest of researchers grew (e.g. Eagles, 2014; Smith et al., 2014; Moyle et al., 2013; Chen et al., 2013; Beh, Bruyere, 2007; Bushell, Griffin, 2006; Eagles, McCool, 2002; Eagles, 2002; Buckley, Sommer 2001; Blamey, Braithwaite, 1997). Some of them are focused on the ecological sustainability, while others explore how to increase the socioeconomic benefits of tourism. Preservation of natural resources is the main mission of protected areas, however, the immense possibilities of outdoor recreation they provide, makes them a suitable place for a highly personalized experience and enjoyment of visitors (Dumitras et al., 2012). According to Tsaur at al. (2006), tourist experiences based on authenticity are one of the most important for increasing the tourism benefits. Considering the great incapability of nature parks in attracting a bigger number of visitors, events based on authenticity could be seen as a possible solution of increasing level of visit.

As already known, events are an important motivator of tourism and figure prominently in the development and marketing plans of most destinations. Planned events within tourism are of increasing importance for destination competitiveness (Getz, 2008) and an effective enhancer of destination image (Hall, 1992). Touristic events are perceived as a one of the effective tools of increasing tourist demand of destinations (Ryan et al., 1998) and as a means of increasing the tourist appeal of destinations to potential visitors (Sherwood, 2007), thus increasing the destination attendance rate and the related investment in the longer term (Dwyer et al., 20oo). In addition, according to Goldblatt (2000), touristic events are perceived as a powerful tool in creating a special tourist experience that can be achieved only in the moment of the event, hence only within a limited period of time, which causes a timely reaction of the arrival of potential tourists at the destination.

Events are an important tool to catch the various economic, social and environmental aims and to make benefits for the communities and destinations (Arcodia, Whitford, 20oo). In addition to this, events do not only serve a destination to attract tourists, they both help to protect and develop social identity at the same time (Derrett, 2004:39). Events play a fundamental role in making foreign tourists stay at a destination for a longer stay as a tourism attraction and making the domestic tourists stay in the country instead of traveling abroad and making them do their tourism expenses in the region (Getz, 1997:52). There are so many advantages of event tourism for the destinations such as attracting tourists (especially in the off-peak season), creating new sources of revenue for the regions, increasing the awareness and attraction of destinations, making the new infrastructure and services or develop the current infrastructure and services, encouraging visitors to make a re-visit to the destination etc (Getz, 1997). Generally, special events are now highly sought, because they are leading to an increased economic activity, as well as to the creation of new jobs (Hussein, 2016; Dwyer et al., 2005) and to the profitability of a tourism destination in which they are taking place (Brent Ritchie, 1984). The events fulfil their main role in the tourist development if they can lead to the achievement of certain positive impacts to the visitors (the fulfilment of expectations or the high level of experience and satisfaction), organizers and the local community (the publicity and a better position of the destination, along with other economic and non-economic effects).

According to previous characteristics, tourism events fit into concept of authentic and sustainable tourism products. Authentic and original tourism products are of great importance 
for destination in order to catch various socioeconomic benefits. Such products are generally in line with the sustainable tourism development, since they (Rotich et al., 2012; MacNulty, Cleverdon, 2011; Sharpley, 2009):

- support local community;

- respect natural and socio-cultural environment;

- differentiate from the competition, avoidance of the "copy-paste development";

- bring significant economic benefit to all involved stakeholders.

Example of touristic event "Knight's Tournament for the Hand of Lady Ružica" (based on authenticity of the area) that traditionally organized in the Nature Park Papuk, greatly contributes to the increasing level of visit (accounting for $28 \%$ of the total annual visit of the Park ${ }^{1}$ ). The initial assumption of the paper is that through organizing touristic events based on previous elements of sustainable tourism supply, PINPs can contribute to the achievement of better economic benefits for themselves and host community as a whole. Therefore, it is relevant to address this issue, examine and identify the perception of other PINPs, according to the defined main objectives of the paper.

\section{Methodology and data analysis}

There are five nature parks in continental Croatia ${ }^{2}$, of a total eleven in Croatia. The continental Croatia covers the northern lowland part (Eastern and Central Croatia) and the northeaster mountain-part of Croatia. The research includes all five-nature parks: Nature Park Kopački rit, Nature Park Papuk, Nature Park Lonjsko polje, Nature Park Medvednica and Nature Park Žumberak - Samoborsko gorje (figure 1.). Most of these nature parks, using the Eurostat Degree of Urbanisation (DEGURBA) - Local Administrative Units, are located in rural areas, i.e. in thinly populated areas, while the some parts are located in intermediate density areas. Only two of them are partly located in densely populated areas - Nature Park Kopački rit (City of Osijek) and Nature Park Medvednica (City of Zagreb). The total area of the nature parks covered by the survey is approximately $1585,9 \mathrm{~km}^{2}$. As far as visits are concerned, nature parks do not count the number of visits in the same way. Some of them notes the exact number of visits (entrance fees), while others are based on estimates. In general, the least visited are nature parks that are far away from larger urban areas (e.g. Nature Park Papuk and Nature Park Lonjsko polje), which receive approximately 7 thousand visits per annum. Others nature parks receive between 35 and 40 thousand visit per annum (exact number or estimate). The main reason of conducting research on these five nature parks in continental Croatia is the fact that they are far away from the major receptive mass tourism destinations that differentiates them from other nature parks, which have a significantly higher level of visit.

In this paper, an empirical research has been conducted with the purpose of determining the possibilities and the limitations in developing and organising events, as the core of the increas-

1 Official website of Nature Park Papuk, data available at: http://pp-papuk.hr/wp-content/uploads/2015/o3/ izvje\% $\mathrm{C}_{5} \% \mathrm{~A} 1 \% \mathrm{C}_{4} \% 87 \mathrm{e}$-o-ostavarivanje-godi\% $\mathrm{C}_{5} \% \mathrm{~A} 1$ njeg-programa-rada-2014.pdf (12.1.2018.)

2 According to the Croatian Government (agreed with Eurostat, in 2012) Croatia is divided into two statistical regions: Continental and Adriatic region. The composition of the Continental region are the city of Zagreb and 13 counties (Zagreb, Krapina-Zagorje, Varazdin, Koprivnica-Krizevci, Međimurje, Bjelovar-Bilogora, ViroviticaPodravina, Pozega-Slavonia, Slavonski Brod, Osijek-Baranja, Srijem, Karlovac and Sisak-Moslavina) 


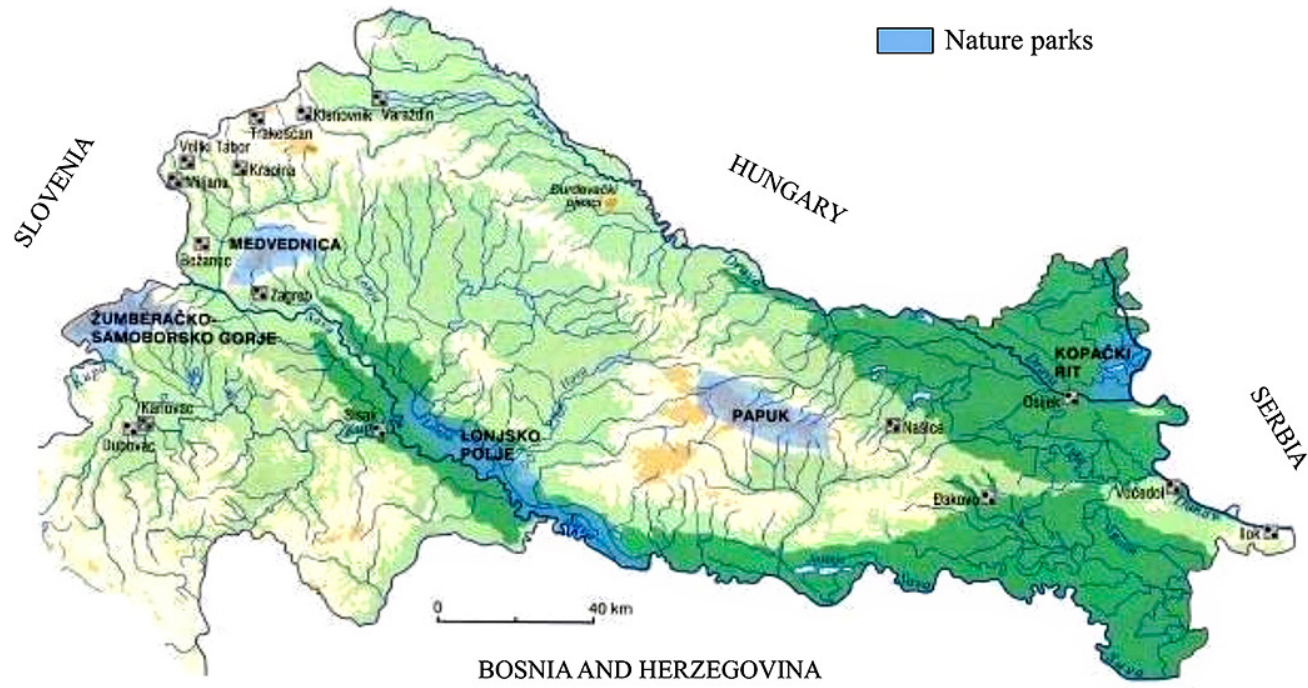

Figure 1. Map of nature parks in Continental Croatia

Source: Adapted to the http://os-grohote solta.skole.hr/nastava/geografija_8/prirodna_i_kulturna_ba_tina_nizinske_ hrvatske (10.4.2018.)

ing level of visit and strengthening the economic sustainability of nature parks. The main aim of the paper is to establish the perception of PINPs, their willingness, but also the main obstacles of organising touristic events. The research is directed at persons who manage nature parks, conducted on a sample of five respondents (the directors of each PINPs). The sample was determined on a previous analysis of the nature park employees. Analysis shows that apart from the directors, none of the employees knows the overall state and direction of the future development of nature parks, since they work on protection and monitoring of the state of nature or tourism and recreational activities. (e.g. nature protection goals and activities, legal regulations, tourism development, new tourism products, tourist and other infrastructure etc.).

According to the small number of respondents, the interview was used in order to obtain relevant primary data, while the obtained data were analysed by the method of descriptive statistics. All five interviews were done by telephone, during the period from July 12th to 16th, 2016. For the purpose of depth data analyses, the respondents' answers were recorded. The semi-structured interview consisted of 15 questions. The interview was conceived as a funnel. In order to reduce the scope of unnecessary information, the interview was semi-structured and divided into five groups of questions:

1. Sociodemographic characteristics of visitors,

2. Products and services available to visitors,

3. The real state of tourism development and organizing events,

4. Number and perception of Nature Park's major benefits of organized touristic events,

5. Limitations in organising touristic events.

In accordance with the defined research objective, basic research questions were set:

1. How do the PINPs assess the state of tourism development in nature parks?

2. Does the leadership of nature parks recognize the significance and benefits that can be achieved by organising tourist events? 
3. Are the restrictions of organising events factors that come from the outdoor or indoor environment of nature parks?

4. Is there a significant correlation between organising events and increasing level of visit and overall sustainability of tourism in nature parks?

In accordance with the defined research questions, the research tasks were defined:

1. Determine the visitor structure and explore which products and services nature parks offer.

2. Examine the number of events organized in the nature parks and explore the key benefits that they have brought them.

3. Examine the key constraints of organising events and determine whether nature parks can affect the removal of certain constraints.

4. Investigate and determine whether there is a significant correlation between organising events and increasing level of visit and generally sustainability of tourism in nature parks.

\section{Research results and discussion}

Analysing the collected data, the structure and main features of the visitors of nature parks, as well as the main products and services are determined. Obtained results indicate that all PINPs constantly monitor the number of visitors and are generally familiar with the visitors' structure. However, the data analysis has determined that not all PINPs are able to monitor the visitor's needs, desires and preferences in a more detailed and appropriate manner due to the lack of qualified staff, and staff in general. As far as supply is concerned, equal services are available on areas of all nature parks, including accommodation, catering services, guidance, interpretation and education, as well as souvenir shopping. In addition, the most frequent visitors are school children, students and mountaineers, who usually visit as organized groups during spring. Besides obtaining the data about tourism capacities and activities in nature parks, this research is also dealing with the perception and attitudes of respondents about touristic events (table 1).

Table 1. The real state of tourism development in nature parks

\begin{tabular}{|l|l|}
\hline $\begin{array}{l}\text { Current situation of tourism in nature parks } \\
\text { (1-completely disagree; 5-completely agree) }\end{array}$ & Mean \\
\hline We will rather invest in nature protection than in tourism development & 1,6 \\
\hline We invest in tourism, but still we are not able to get the refund of invested means & 5,0 \\
\hline National tourism policy does not support the tourism development in nature parks & 2,8 \\
\hline Nature protection and environment policy has an negative effect or limit tourism development of in nature parks & 1,6 \\
\hline
\end{tabular}

Source: Authors, according to the conducted research

As seen from above, the major limiting factor of tourism development in nature parks is insufficient return of the invested funds. All respondents added that the current situation is not sustainable and the amount of investments are not equal or lower from profits moreover, losses are growing. Furthermore, data analysis indicate that there is no legislation restriction at all, given their targeted development of tourism and inclinations or commitments for greater investment in nature protection versus tourism (average mark 1,6 ). The most of the respond- 


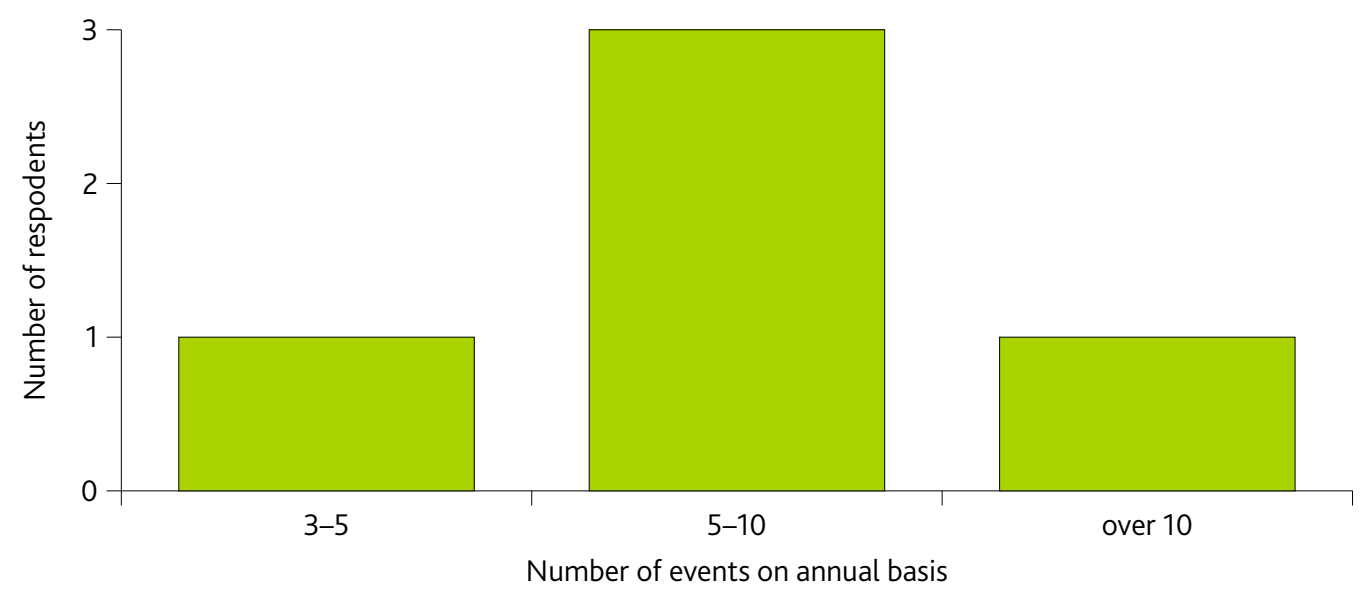

Figure 2. Number of organized touristic events on an annual basis Source: Authors, according to the conducted research

ents explain that they equally invest in the development of tourism, as well as in nature conservation. In addition, they did not express complete satisfaction with the National Tourism Policy, which they rated as mediocre. The main reason of this mediocre satisfaction is that they do not have enough support of tourism development, as they administratively belonged to the Ministry of Environment and Energy. Furthermore, given the main purpose of the paper, the number of touristic events organized in the nature parks area was determined, as shown in figure 2.

According to the figure 2, nature parks organise on average five to ten events annually, including events of global environment and nature protection. However, respondent stated that the most of these events are part of non-commercial (e.g. World Environment Day, Earth Day, Mountain Day, etc.).

As for the organising of touristic events (table 2), all respondents with the highest rated mark $(5,0)$ fully agree that they contribute to the increasing level of visit, but emphasize their complete economic unsustainability $(1,4)$. All respondents explained that there is a great interest of visitors in the period when tourist events are organized and even entrance fees are charged, organizational costs are larger than the profit. Other organized events that are part of non-commercial movement (e.g. World Environment Day, Earth Day, etc.) are less funded and mostly visited by individuals without paying entrance fees. Therefore, organized touristic events are generally unprofitable for nature parks.

Table 2. The current situation of organising events in nature parks

\begin{tabular}{|l|l|}
\hline $\begin{array}{l}\text { Current situation of organising events in nature parks } \\
\text { (1-completely disagree; } 5 \text {-completely agree) }\end{array}$ & Mean \\
\hline Potential partners are interested in organising or taking part in events in nature parks & 2,6 \\
\hline There is economic feasibility (cost-effectiveness) in organising events in nature parks & 1,4 \\
\hline Touristic events are recognized as means of appealing bigger number of visitors and making benefits for nature parks & 5,0 \\
\hline
\end{tabular}

Source: Authors, according to the conducted research.

Further, all respondents point out that the interest of some stakeholders for cooperation in organising events is mediocre (average mark 2, 6). Because of current situation, they emphasize that local stakeholders do not recognize the potential benefits of such cooperation. However, 
cooperation and partnership in tourism is an imperative. PINPs should tend to cooperate with local and regional stakeholders (e.g. local and regional governments, Tourism Boards, entrepreneurships, NGOs, etc.). Such cooperation will increase positive tourism effects in nature parks (better position of tourism, more investment in tourism development, better quality of tourism products and services, increases of revenue, inclusion and enforcement of locals in tourism, etc.).

It is obvious that touristic events cannot contribute to the economic sustainability of nature parks by charging fees only. The main reason of non-profitability of organized touristic events is that PINPs mostly self-organize events and there are not enough other accompanying tourism facilities in order to generate additional revenue. In addition, PINPs usually organize events connected with global environment and nature protection, which are just a cost in economic terms. Hence, PINPs should focus more on specialized, authentic touristic events in order to achieve not only significant visitation increase, but also economic benefits from organized event.

In order to collect comprehensive data, the research determines whether there are certain limitations in the development and organising events (figure 3). Data analysis showed that high rated limitation is impossibility of investment refund (average mark 1,3) and insufficient financial funds $(1,7)$, followed by a lack of financial means for organisation of touristic events. Thus, the obtained information confirms that touristic event do not contribute to the economic sustainability of nature parks, since they are not sustainable either, as respondents emphasized before. The least restrictive factor relates to the legal regulations. According to the explanation of the respondents, laws of nature and environment protection in nature parks do not limit the carrying out of such activities.

Furthermore, after determining the key effects, the respondents evaluated in detail the individual economic and non-economic benefits of the organized touristic events (Table 3). Accordingly, the aim was to determine more precisely whether they see their positive aspects or not. By analysing the data obtained, it is evident that all respondents are supporting the organization of such events. In addition, all respondents agreed that organising touristic events fully contributes to the quality of touristic experience and encourages visitors to return

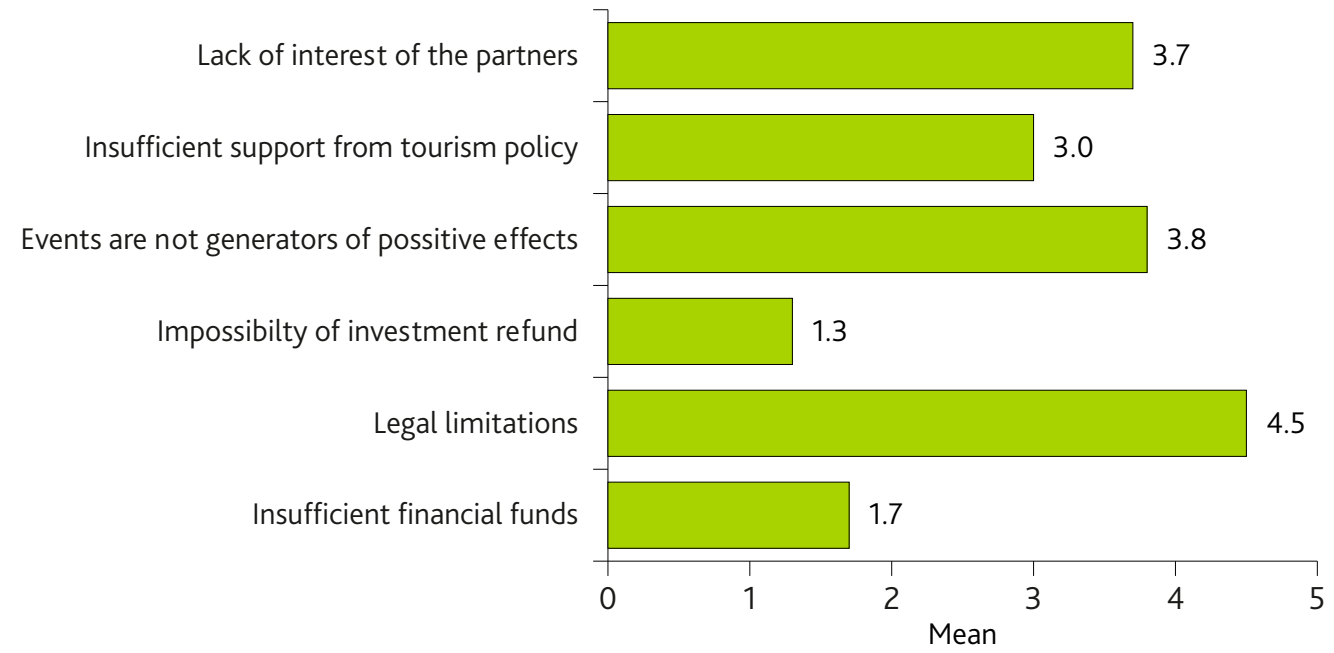

Figure 3. The main reasons and limitations of organising a small number of touristic events Source: Authors, according to the conducted research 
in nature parks (average mark 5, o). Likewise, contribution of touristic events to the promotion and strengthening of the demand for visiting nature parks are ranked high $(4,8)$, as well as the opportunity for networking and including the private sector in enriching the tourist supply of nature parks $(4,6)$ and strengthening off peak season level of visit of nature parks $(4,4)$.

Table 3. Nature parks' major benefits of organising touristic events

\begin{tabular}{|l|c|}
\hline $\begin{array}{l}\text { Nature Parks' major benefits of organising touristic events } \\
\text { (1-completely disagree; 5-completely agree) }\end{array}$ & Mean \\
\hline Organising events significantly influences on increasing the number of visitors in nature parks & 3,8 \\
\hline Organising events contributes to promotion and strengthening of demand for visiting nature parks & 4,8 \\
\hline Organising events highlights touristic experience in nature parks and encourages the visitors to return again & 5,0 \\
\hline $\begin{array}{l}\text { Organising events is an opportunity for networking and including the private sector in enriching the tourist supply } \\
\text { of nature parks }\end{array}$ & 4,6 \\
\hline Organising events in nature parks is an opportunity for significant income increase & 3,4 \\
\hline Organising events contributes to strengthening off peak season level of visit of nature parks & 4,4 \\
\hline
\end{tabular}

Source: Authors, according to the conducted research.

As the less positive effect of organizing touristic events, respondents ranked significant income increase $(3,4)$. As main reasons, respondents explain that their revenue is weaker due to the impossibility of charging fees to all visitors and insufficient interest of local and regional stakeholders during the period of holding touristic events (e.g. charging concessions, donations, sponsorships, partnerships in the organization, etc.). Such of revenue collection would increase total amount of revenues and could reduce costs (e.g. divided costs of the organisation). Additionally, that can be opportunity for raising earnings.

In order to achieve the economic sustainability of events, the PINPs should use the possibility of cooperation and collaboration with the public, private and non-profit sector, since the legal regulation is not a limiting factor (average mark 3, 7). By quality cooperation and collaboration, PINPs share financial risk with other stakeholders, enhance promotion of the touristic events, etc., thereby affecting the overall visitor experience. As Eagles et al. (2002) stated, enhanced cooperation among the tourism industry, governments at all levels, local communities, protected area managers and planners will ensure that tourism contributes to the sustainable management of protected areas. Furthermore, the question arises how and why events organized in nature parks contribute to the increasing level of visit, but not to economic benefits. The answer lies in the fact that nature parks organize events that usually, with the realization of the goals of protection, are not based on profitability, but are primarily directed towards the social component.

According to the above mentioned, it is a challenge of each nature parks to create touristic events based on uniqueness of its natural, environmental, socio-cultural and economic characteristics in cooperation with interested stakeholders. Authenticity certainly presents a prominent motive and significant value for a modern tourist, who in search for authenticity looks for untouched natural and cultural products in order to achieve a high level of tourist experience (Cohen, 1988). Accordingly, an analysis of theoretical and empirical data shows that there is a growing desire for tourists' experience and products, which are original and authentic (Yeoman et al., 2007). Tourism practice has shown that by achieving a high level of touristic experience, multiple benefits can be expected, such as increased spending per visitor, return and promotion of destinations closest to oneself as well as social networks. All these circumstances are an ideal opportunity for further tourism development and economic sustainability 
of nature parks, but also a challenge for park management to attract more visitors, meet their needs, desires and expectations, together with nature preservation.

Many protected areas have successfully achieved their conservation objectives, thanks to the financial resources that have been obtained through visitors' expenditures (Yunis, 2006; Bushell, Eagles, 2006). Bushell et al. (2006) stated that the lack of funding would influence on future developments and maintaining existing protected areas. Therefore, tourism seems to be fundamental for a public and political support of parks and protected areas. It concludes that, despite the pleas of environmentalists, the establishment and continued existence of protected areas will depend largely on market forces. While the need for conservation and preservation measures is becoming more and more important, the financing of protected areas through the government funds is becoming increasingly difficult. As a result, many protected areas, may have become "paper parks“ (Dharmaratne et al., 200o). According to the data obtained, PINPs invest in the tourism development, because they realize that tourism is extremely important for the achievement of Nature Park's missions, both to achieve the primary goals of protection and conservation, as well as strengthening the overall sustainability of nature parks and the community as a whole. The results of empirical research conducted by the authors generally indicate that touristic events are the best tool for promotion, achieving a tourist experience and attracting more visitors, but on the other side, they are economic unsustainable and cannot contribute to the financial state of the nature parks.

\section{Conclusion}

The tourism supply of nature parks must strive to provide a new, unique, innovative, modern and socially acceptable value, according to the needs of contemporary tourist demand (e.g. design, quality standards, elements of sustainability etc.). It is a well-known fact that the survival of protected areas today largely depends on their economic forces and they are therefore highly focused on tourism and increasing level of visit. Although nature parks are investing equally in the development of tourism, as well as in nature protection, tourism investments are now higher than the refund of investment. According to the conducted research, tourist events contribute significantly to promotion, tourist experience and increasing level of visit, but not to the economic sustainability of nature parks. Although the research found that PINPs have multiple benefits of organizing events (e.g. increasing the number of visitors, increasing promotion, high level of touristic experience, strengthening off peak season visits etc.), they organize a small number on an annual basis due to their unprofitability.

Considering that the lack of financial resources and unprofitability of touristic events are the main limitation of organising their larger number, the PINPs need to find solutions to these constraints in order to continue to absorb the above-mentioned benefits through organising profitable touristic events. Taking into account the fact that cooperation and collaboration are not a limiting developmental factor, nature parks should focus more on collaboration with local interested stakeholders in organising tourism events. It is assumed that by collaboration and cooperating with stakeholders from the public, civil and private sector, nature parks could strengthen the segment of profitability of the events (e.g. donations, concession during the events, additional tourism supply and facilities, higher entrance fees, etc.). It is to expect that such multi-sector approach would ensure higher events quality that will provide unique touristic experience. Additionally, such events must be focused and promoted among target groups of tourists in order to be more profitable. 
On the other hand, in such circumstances it is extremely important that a newly created touristic event does not interfere with environmental policy, does not conflict with the local community, or the interests of the wider community (e.g. disturbing cultural, natural and other features of the site). Creating and organising unique, authentic events in nature parks would create benefit, based on authenticity of certain area. As it is well known that visitors want a new, unique, personalized experience, a supply based on such events may contribute to better economic situation of nature parks. Therefore, in order to increase economic sustainability of nature parks, it is desirable to consider the findings in this paper and to examine in more detail the possible solutions mentioned.

According to the above-mentioned assumptions, future research should investigate in more detail, if touristic events can and in what kind of proposed solution contribute to the economic sustainability of nature parks. Further, it is necessary to compare economic influence between non-commercial and authentic touristic events, as both already contribute to the increasing level of visit and other non-economic elements. Third, further research should include more respondents (e.g. other employees of nature parks and tourists) in order to have results that are more precise.

\section{References}

Arcodia, C., Whitford, M. 2007. Festival attendance and the development of social capital. Journal of Convention E Event Tourism 8(2), 1-18.

Beh, A., Bruyere, B. L. 2007. Segmentation by visitor motivation in three Kenyan national reserves. Tourism management 28(6), 1464-1471.

Blamey, R. K., Braithwaite, V. A. 1997. A social values segmentation of the potential ecotourism market. Journal of Sustainable Tourism 5(1), 29-45.

Brent Ritchie, J. R. 1984. Assessing the impact of hallmark events: Conceptual and research issues. Journal of travel research 23(1), 2-11.

Buckley, R. C., Sommers, M. 2001. Tourism and protected areas: Partnerships in principle and practice. CRC for Sustainable Tourism.

Bushell, R., Eagles, P. F. (Eds.) 2006. Tourism and protected areas: benefits beyond boundaries, The Vth IUCN World Parks Congress. Wallingford: CABI.

Bushell, R., Griffin, T. 2006. Monitoring visitor experiences in protected areas. The International Journal for Protected Area Managers 16(2), 25-33.

Bushell, R., Staiff, R., Eagles, P. F. 2006. Tourism and protected areas: benefits beyond boundaries. In: Bushell, R., Eagles, P. F. (Eds.) Tourism and protected areas: benefits beyond boundaries, The Vth IUCN World Parks Congress. CABI, Wallingford, 1-11.

Chen, J. S., Prebensen, N. K., Chen, Y. L., Kim, H. 2013. Revelation of nature-minded travelers: A study of the Swedish. Tourism Analysis 18(6), 651-661.

Cohen, E. 1988. Authenticity and commoditization in tourism. Annals of tourism research 15(3), 371-386.

Dharmaratne, G. S., Sang, F. Y., Walling, L. J. 200o. Tourism potentials for financing protected areas. Annals of Tourism Research 27(3), 590-610.

Derrett, R. 2004. Festivals, Events and the Destination. In: Yeoman, I. et al. (Eds) Festival and Events Management: An International Arts and Culture Perspective. Elsevier Butterworth Heinemann, Amsterdam, 32-64. 
Dumitraş, D. E., Ilea, M., Arion, F. H., Jitea, I. M. 2012. Tourists' preferences for outdoor recreation and nature tourism in Romania. Lucrari Stiintifice Seria I 14(4), 59-64.

Dwyer, L., Forsyth, P., Spurr, R. 2005. Estimating the impacts of special events on an economy. Journal of travel research 43(4), 351-359.

Dwyer, L., Mellor, R., Mistilis, N., Mules, T. (200o). A framework for evaluating and forecasting the impacts of special events. In: Allen, J., et al., (Ed.), Events Beyond 200o, Proceedings of Conference on event evaluation, research and education, (31-45). Sydney: Australian Centre for Event Management.

Eagles, P. F. J. 2014. Research priorities in park tourism. Journal of Sustainable Tourism 22(4), 528-549.

Eagles, P. F. J. 2002. Trends in park tourism: Economics, finance and management. Journal of Sustainable Tourism 10(2), 132-153.

Eagles, P. F., McCool, S. F. 2002. Tourism in national parks and protected areas: Planning and management. Wallingford, CABI.

Eagles, P. F. J., McCool, S. F., Haynes, C. D. 2002. Sustainable Tourism in Protected Areas: Guidelines for Planning and Management. IUCN, Gland, Switzerland and Cambridge, UK.

Getz, D. 1997. Event management $\mathcal{E}$ event tourism. Cognizant Communication Corporation, New York.

Getz, D. 2008. Event Tourism: Definition, Evolution and Research. Tourism Management 29(1), 403-4.28.

Goldblatt, J. (200o). A future for event management: the analysis of major trends impacting the emerging profession. In: Allen, J., et al., (Ed.), Events Beyond 20oo, Proceedings of Conference on event evaluation, research and education, (2-9). Sydney: Australian Centre for Event Management.

Government of the Republic of Croatia 2015. Report on the state of nature in the Republic of Croatia for the period 2008-2012, available on the official website of the Croatian Parliament: http://www.sabor.hr/izvjesce-o-stanju-prirode-u-republici-hrvatskoj-za (10.1.2018.)

Hall, C. M. 1992. Hallmark tourist events: impacts, management and planning. Belhaven Press, London.

Hussein, A. S. 2016. How Event Awareness, Event Quality and Event Image Creates Visitor Revisit Intention?: A Lesson from Car free Day Event. Procedia Economics and Finance 35, 396-400.

MacNulty, P., Cleverdon, R. 2011. Handbook on Tourism Destination Branding. World Tourism Organization and European Travel Commision.

Mayer, M. 2014. Can nature-based tourism benefits compensate for the costs of national parks? A study of the Bavarian Forest National Park, Germany. Journal of Sustainable Tourism 22(4), 561-583.

Moyle, B. D., Weiler, B., Croy, G. 2013. Visitors' perceptions of tourism impacts: Bruny and Magnetic Islands, Australia. Journal of Travel Research 52(3), 392-406.

Nature Protection Act Republic of Croatia (NN, 8o/13), available at: http://narodne-novine. nn.hr/clanci/sluzbeni/2013_o6_8o_1658.html.

Official website of Nature Park Papuk, data available at: http://pp-papuk.hr/wp-content/ uploads/2015/o3/izvje\%C5\%A1\%C4\%87e-o-ostavarivanje-godi\% $\mathrm{C}_{5} \% \mathrm{~A} 1$ njeg-programa-rada-2014.pdf (12.1.2018.)

Rotich, D., Nthiga, R., Bor, T., Kogola, B. 2012. Product Diversification for Sustainable Tourism Development: Exploring The Strenghts and Challenges of Kisumu Region, Kenya. European Journal of Business and Social Sciences 1(9), 108-117. 
Sharpley, R. 2009. Tourism development and the Environment: Beyond Sustainability? Earthscan, London.

Sheppard, D. 2006. Foreword. In: Bushell, R., Eagles, P. F. (Eds.) Tourism and protected areas: benefits beyond boundaries, The Vth IUCN World Parks Congress. CABI, Wallingford, xii-xiii.

Sherwood, P. 2007. A triple bottom line evaluation of the impact of special events: The development of indicators. Doctoral dissertation, Victoria University.

Smith, A. J., Tuffin, M., Taplin, R. H., Moore, S. A., Tonge, J. 2014. Visitor segmentation for a park system using research and managerial judgement. Journal of Ecotourism 13(2-3), 93-109.

Tsaur, S. H., Chiu, Y. T., Wang, C. H. 2007. The visitors behavioral consequences of experiential marketing: an empirical study on Taipei Zoo. Journal of Travel E Tourism Marketing 21(1), 47-64.

Yeoman, I., Brass, D., McMahon-Beattie, U. 2007. Current issue in tourism: The authentic tourist. Tourism Management 28(4), 1128-1138.

Yunis, E. 2006. Perface. In: Bushell, R., Eagles, P. F. (Eds.) Tourism and protected areas: benefits beyond boundaries, The Vth IUCN World Parks Congress. CABI, Wallingford, xiv-xvi. 